\title{
Pelatihan E-Learning Moodle Berbasis Cloud Untuk Tutor/Guru Pusat Kegiatan Belajar Masyarakat (PKBM)
}

\author{
Albaar Rubhasy $^{1}$; Raden Muhammad Firzatullah²; Riad Sahara ${ }^{3}$ \\ 1,2,3 Universitas Nasional \\ Fakultas Teknologi Komunikasi dan Informatika \\ ${ }^{1}$ albaar.rubhasy@ civitas.unas.ac.id
}

\begin{abstract}
The Community Learning Activity Center (PKBM) is a non-formal education unit that provides educational services for people in need. Currently PKBM uses face-to-face learning methods in classrooms, so it is not optimal for learning citizens because interaction with tutors can only be done in the PKBM environment. On the other hand, e-learning technology can make it easier for PKBM tutors / teachers in implementing learning because learning can be done anytime and anywhere according to the abilities of the teaching participants. The main objective of this community service activity is to provide training in the use of cloud-based Moodle e-learning for PKBM tutors / teachers. The implementation methods consist of: (1) Needs Analysis; (2) CloudMoodle implementation; (3) Preparation of Training Materials; (4) Data Collection of Prospective Training Participants; (5) Creating PKBM Tutor / Teacher Accounts; and (6) Evaluation and Reporting. The training was attended by 31 participants from 10 PKBM institutions. The training material is delivered interactively with materials including: (i) a general explanation of the Moodle application; (ii) learning material management training; and (iii) Value management training. Based on the results of the evaluation, the training activities were well organized based on the feedback given by the participants in terms of three aspects: (i) the participants' understanding of the training material; (ii) providing training; and (iii) training resource persons.
\end{abstract}

Keywords: PKBM, e-learning, Moodle, cloud-based system

\begin{abstract}
ABSTRAK
Pusat Kegiatan Belajar Masyarakat (PKBM) merupakan satuan pendidikan non-formal yang memberikan layanan pendidikan bagi masyarakat yang membutuhkan. Saat ini PKBM menggunakan metode belajar tatap muka di ruang kelas, sehingga kurang optimal bagi warga belajar karena interaksi dengan para tutor hanya dapat dilakukan di lingkungan PKBM. Di sisi lain, teknologi e-learning dapat memberikan kemudahan bagi tutor/guru PKBM dalam penyelenggaraan pembelajaran karena pembelajaran dapat dilakukan kapan pun dan dimana pun sesuai dengan kemampuan peserta ajar. Tujuan utama kegiatan pengabdian masyarakat ini adalah untuk memberikan pelatihan penggunaan e-learning Moodle berbasis cloud untuk tutor/guru PKBM. Adapun metode pelaksanaan terdiri dari: (1) Analisis Kebutuhan; (2) Implementasi CloudMoodle; (3) Penyusunan Materi Pelatihan; (4) Pendataan Calon Peserta Pelatihan; (5) Pembuatan Akun Tutor/Guru PKBM; dan (6) Evaluasi dan Pelaporan. Pelatihan diikuti oleh 31 peserta yang berasal dari dari 10 institusi PKBM. Materi pelatihan disampaikan secara interaktif dengan materi antara lain: (i) penjelasan umum mengenai aplikasi Moodle; (ii) pelatihan pengelolaan materi pembelajaran; dan (iii) Pelatihan pengelolaan nilai. Berdasarkan hasil evaluasi, kegiatan pelatihan telah diselenggarakan dengan baik berdasarkan umpan balik yang disampaikan oleh peserta dipandang dari tiga aspek: (i) pemahaman peserta terhadap materi pelatihan; (ii) penyelenggaraan pelatihan; dan (iii) narasumber pelatihan.
\end{abstract}

Kata kunci: PKBM, e-learning, Moodle, sistem berbasis cloud 


\section{PENDAHULUAN}

Pendidikan merupakan hak setiap warga negara. Hal ini dijamin oleh Undang-Undang Dasar Negara Republik Indonesia Tahun 1945 pada Pasal 31 ayat (1) yang menyebutkan bahwa setiap warga negara berhak mendapat pendidikan [1]. Pendidikan dapat diperoleh melalui tiga jalur: pendidikan formal, non formal, dan informal. Hal ini sejalan dengan Undang-Undang Republik Indonesia Nomor 20 Tahun 2003 tentang Sistem Pendidikan Nasional pada Pasal 13 ayat (1) [2]. Untuk memenuhi kebutuhan belajar tingkat dasar dapat dilakukan melalui pendidikan formal dan non formal, sebagaimana yang telah diatur dalam Peraturan Pemerintah Republik Indonesia Nomor 17 Tahun 2010 tentang Pengelolaan dan Penyelenggaraan Pendidikan [3]. Untuk itu pada tahun 2015, pendidikan berkualitas dicanangkan sebagai salah satu Tujuan Pembangunan Berkelanjutan (TPB) atau Sustainable Development Goals tahun 2015-2030 [4] dan isu pendidikan menjadi salah satu prioritas dalam Rencana Pembangunan Jangka Menengah Nasional 2020-2024 [5].

Untuk meningkatkan Angka Partisipasi Kasar (APK), Pemerintah mengatur penyelenggaraan pendidikan nonformal yang meliputi penyelenggaraan satuan pendidikan dan penyelenggaraan program pendidikan non formal dan Pusat Kegiatan Belajar Masyarakat (PKBM) merupakan salah satu satuan pendidikan non formal [3]. PKBM sebagai satuan pendidikan nonformal dapat menyelenggarakan program pendidikan non formal yang meliputi pendidikan kecakapan hidup, pendidikan anak usia dini, pendidikan kepemudaan, pendidikan pemberdayaan perempuan, pendidikan keaksaraan, pendidikan keterampilan dan pelatihan kerja, pendidikan kesetaraan dan pendidikan non formal lain yang diperlukan masyarakat.

Pusat Kegiatan Belajar Masyarakat (PKBM) merupakan satuan pendidikan non-formal yang memberikan layanan pendidikan bagi masyarakat yang membutuhkan. PKBM merupakan institusi yang berbasis masyarakat (community based institution) dengan prinsip penyelenggaraan yang dilakukan oleh masyarakat dan untuk masyarakat. Oleh karena itu, keberlangsungan dan keberlanjutan PKBM merupakan tanggung jawab dari masyarakat dan mitra PKBM. Beberapa fungsi yang PKBM sebagai antara lain [6]:

1) Tempat masyarakat belajar (learning society)

2) Tempat tukar belajar (learning exchange)

3) Pusat pengetahuan dan informasi atau perpustakaan masyarakat

4) Sebagai sentra pertemuan berbagai lapisan masyarakat

5) Pusat penelitian masyarakat (community research center) terutama dalam pengembangan pendidikan nonformal

Program kesetaraan merupakan program Pemerintah untuk mengatasi masalah tingginya angka putus sekolah pada pendidikan dasar dan menengah. PKBM menyediakan layanan program Kelompok Belajar Paket A (setara SD/MI), Paket B (setara SMP/MTs), dan Paket C (setara SMA/MA). Berdasarkan Peraturan Pemerintah Nomor 47 Tahun 2008 tentang Wajib Belajar, maka seluruh masyarakat harus membantu terselenggaranya program pendidikan hingga setingkat SMP/MTs atau yang dikenal dengan program "Wajib Belajar 9 Tahun" [7]. Sedangkan masih terdapat banyak anak yang tidak dapat melanjutkan pendidikan sekolah dasar ke jenjang sekolah menengah akibat faktor ekonomi maupun sosial. Sedangkan melalui kemajuan teknologi informasi dan komunikasi (TIK), membuka peluang seluas-luasnya terhadap peningkatan akses pendidikan yang berkualitas melalui konsep e-learning. Oleh karena itu, PKBM diusulkan sebagai fokus utama pada kegiatan Pengabdian Kepada Masyarakat (PKM) dengan fokus pada pemberdayaan tutor/guru PKBM untuk lebih memahami dan menguasai teknologi e-learning. 


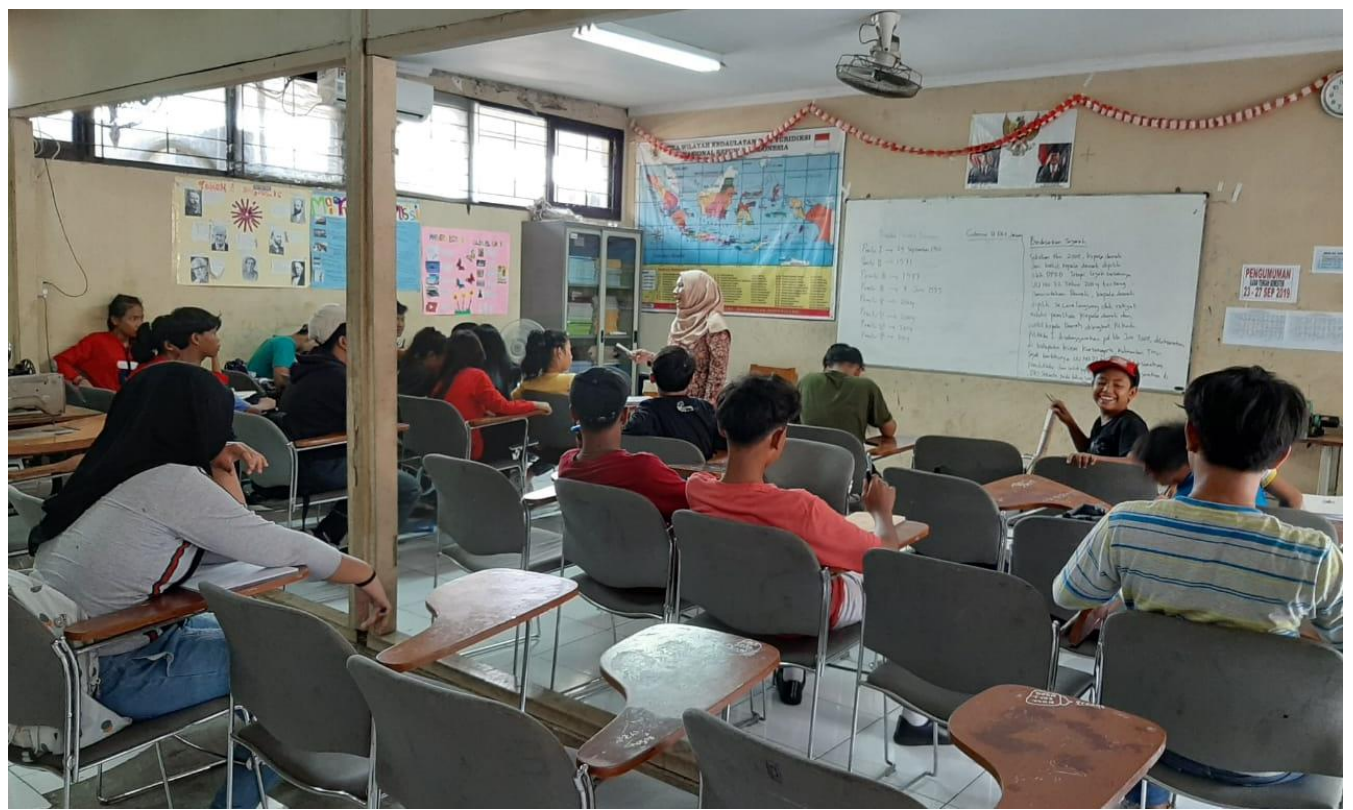

Gambar 1. Suasana Belajar di PKBM Negeri 23 Jakarta Pusat

(Sumber: pkbmnegeri23jakpus.wordpress.com)

Rogers menyatakan bahwa PKBM memiliki peran penting dalam pencapaian sasaran TPB ke-4, yaitu pendidikan berkualitas [8]. Untuk mencapai sasaran tersebut perlu didukung oleh teknologi e-learning. Salah satu keunggulan penggunaan teknologi e-learning dalam pendidikan non formal adalah aktivitas belajar dapat dilakukan secara sinkron dan asinkron [9].

\section{METODE}

Pelaksanaan PKM diawali dengan analisis kebutuhan mitra PKBM dalam kegiatan belajar mengajar. Setelah seluruh kebutuhan sumber daya pembelajaran dianalisis, tahap selanjutnya adalah melakukan implementasi CloudMoodle. Implementasi dilakukan menggunakan akun ujicoba atau trial dengan masa berlaku selama 3 (tiga) bulan. Sebagai persiapan dalam pelaksanaan pelatihan, tahap berikutnya adalah penyusunan materi pelatihan yang terdiri dari materi pengantar dan petunjuk penggunaan Moodle. Kemudian tahap selanjutnya adalah pendataan calon peserta pelatihan yang berasal dari berbagai PKBM yang ada di wilayah DKI Jakarta dan sekitarnya. Setelah dilakukan pendataan calon peserta pelatihan, selanjutnya adalah pembuatan akun tutor/guru PKBM di CloudMoodle agar para peserta dapat mempraktekkan langsung materi pelatihan menggunakan akun masing-masing peserta. Kemudian tahap berikutnya adalah pelaksanaan pelatihan yang dilakukan secara virtual menggunakan zoom. Tahap terakhir evaluasi pelaksanaan PKM menggunakan angket yang disebar melalui google form serta pembuatan laporan. Gambaran metode pelaksanaan PKM dapat dilihat pada Gambar 2. 


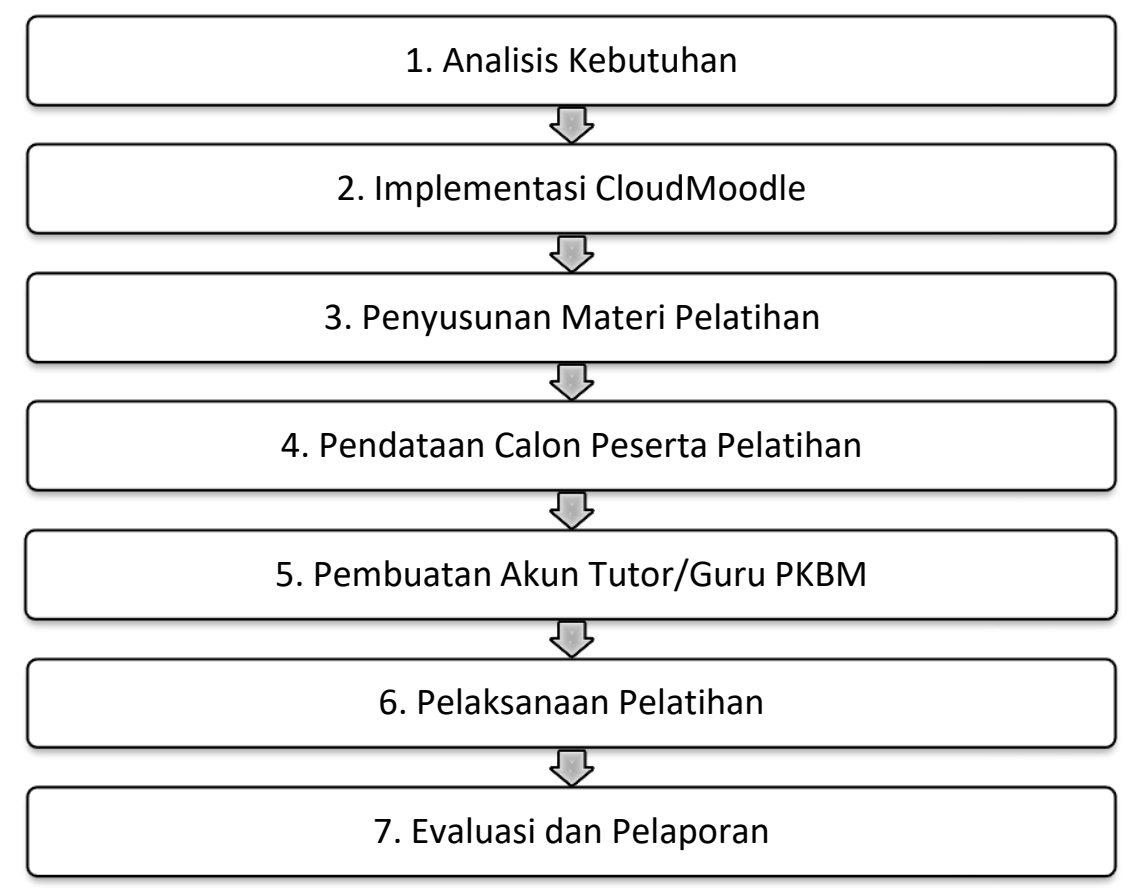

Gambar 2. Tahapan Pelaksanaan PKM

Metode pelaksanaan pelatihan CloudMoodle dilakukan secara interaktif dan setiap peserta dapat mempraktekkan langsung setiap instruksi yang disampaikan oleh fasilitator pelatihan melalui perangkat komputer dan ponsel pintar yang dimilikinya. Langkah-langkah dalam pelaksanaan pelatihan adalah sebagai berikut:

1) Peserta diberi penjelasan umum mengenai e-learning Moodle beserta fitur-fiturnya

2) Peserta mencoba login menggunakan akun Moodle yang telah diberikan oleh panitia

3) Peserta diberi penjelasan mengenai cara mengunggah materi ajar, membuat kuis, tugas, dan forum diskusi

4) Peserta diberi kesempatan untuk mempraktekkan cara mengunggah materi ajar, membuat kuis, tugas, dan forum diskusi

5) Peserta diberi penjelasan mengenai cara membuat penilaian dan mengunduh nilai siswa

6) Peserta diberi kesempatan untuk mempraktekkan cara membuat penilaian dan mengunduh nilai siswa

7) Pengisian angket evaluasi pelatihan dan pembagian sertifikat kehadiran

\section{HASIL DAN PEMBAHASAN}

Kegiatan PKM "Pelatihan E-Learning Dengan Aplikasi Moodle Untuk Tutor/Guru PKBM" diselenggarakan pada tanggal 6 Juli 2020 pukul 10.00-12.00 WIB dengan total peserta sebanyak 31 tutor/guru PKBM yang mewakili lebih dari 10 institusi PKBM berbeda. Suasana pelatihan ELearning Moodle secara virtual dapat dilihat pada Gambar 3. 


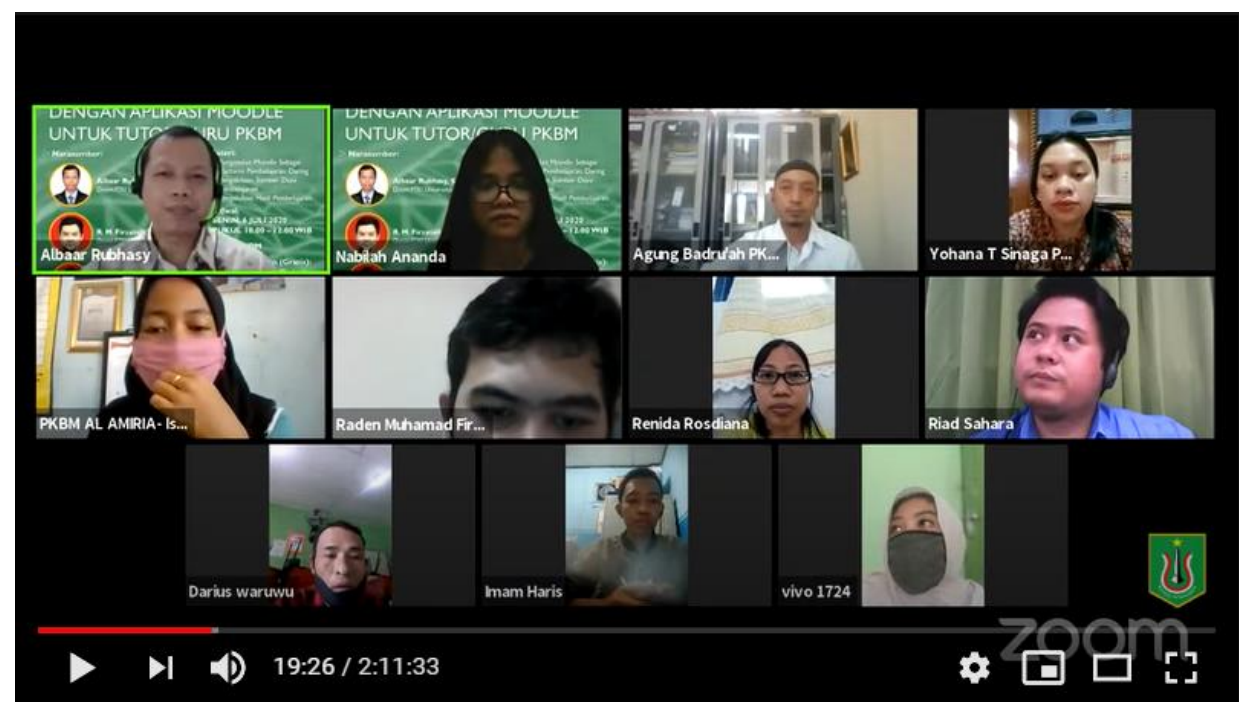

Gambar 3. Suasana Pelatihan E-Learning Moodle Secara Virtual

Berdasarkan kuesioner yang diisi peserta pelatihan, mayoritas peserta pelatihan berjenis kelamin perempuan yaitu sebanyak 20 orang $(64,5 \%)$ dan laki-laki 11 orang $(35,5 \%)$. Kemudian berdasarkan usia, rentang usia 31-45 tahun berjumlah 17 orang $(54,8 \%)$ dan 18-30 berjumlah 14 orang $(45,2 \%)$. Adapun pengalaman mengajar peserta cukup beragam, peserta dengan pengalaman mengajar 0-5 tahun sebanyak 17 orang (54,8\%), 6-10 tahun sebanyak 10 orang (32,3\%), dan 11-15 tahun sebanyak 4 orang $(12,9 \%)$. Karakteristik peserta pelatihan dirangkum pada Tabel 1-3.

Tabel 1. Karakteristik Peserta Pelatihan Berdasarkan Jenis Kelamin

\begin{tabular}{|c|c|c|}
\hline Jenis Kelamin & Frekuensi & Persentase(\%) \\
\hline Laki-laki & 11 & $35,5 \%$ \\
\hline Perempuan & 20 & $64,5 \%$ \\
\hline Total & 31 & $100 \%$ \\
\hline
\end{tabular}

Tabel 2. Karakteristik Peserta Pelatihan Berdasarkan Usia

\begin{tabular}{|c|c|c|}
\hline Usia & Frekuensi & Persentase(\%) \\
\hline $18-30$ tahun & 14 & $45,2 \%$ \\
\hline $31-45$ tahun & 17 & $54,8 \%$ \\
\hline $46-59$ tahun & 0 & $0 \%$ \\
\hline$>60$ tahun & 0 & $0 \%$ \\
\hline Total & 31 & $100 \%$ \\
\hline
\end{tabular}

Tabel 3. Karakteristik Peserta Pelatihan Berdasarkan Pengalaman Mengajar

\begin{tabular}{|c|c|c|}
\hline Usia & Frekuensi & Persentase(\%) \\
\hline $0-5$ tahun & 17 & $54,8 \%$ \\
\hline $6-10$ tahun & 10 & $32,3 \%$ \\
\hline $11-15$ tahun & 4 & $12,9 \%$ \\
\hline$>15$ tahun & 0 & $0 \%$ \\
\hline Total & 31 & $100 \%$ \\
\hline
\end{tabular}


Berdasarkan kuesioner juga diperoleh bahwa mayoritas peserta pernah menggunakan aplikasi e-learning, yaitu sebanyak 18 peserta $(58,1 \%)$ dan yang belum pernah menggunakan sebanyak 13 peserta $(41,9 \%)$. Adapun aplikasi e-learning yang paling banyak digunakan adalah Google Classroom (lihat Gambar 4). Kemudian motivasi penggunaan e-learning sebagian besar menyatakan adalah untuk memberikan kemudalam dalam mengelola materi pembelajaran (lihat Gambar 5).

Aplikasi E-Learning/LMS yang pernah digunakan (jawaban boleh lebih dari satu)

18 responses

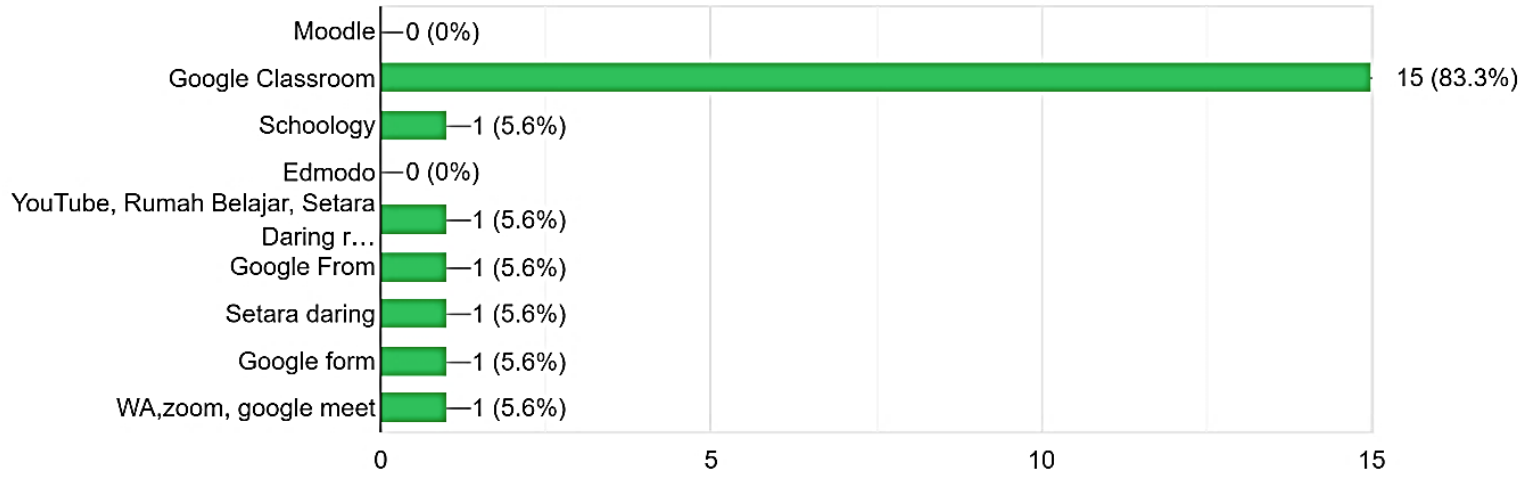

Gambar 4. Aplikasi E-Learning Yang Pernah Digunakan Peserta

Alasan Menggunakan E-Learning/LMS (jawaban boleh lebih dari satu)

18 responses

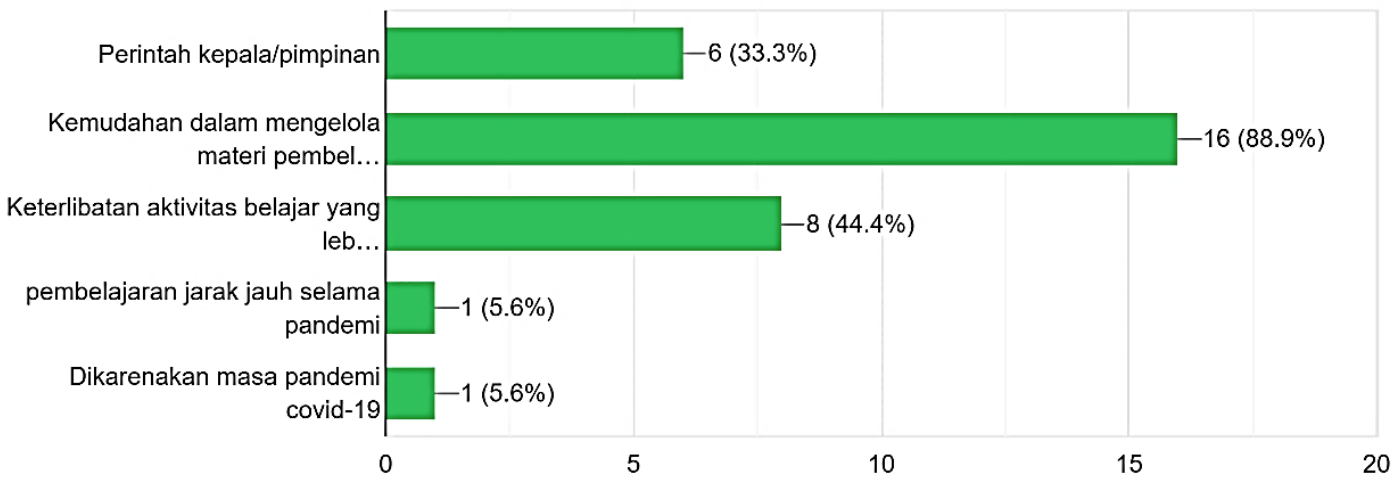

Gambar 5. Alasan Peserta Dalam Menggunakan E-Learning

Kegiatan pelatihan ini bersifat interaktif dan peserta dapat mempraktekkan sendiri setiap instruksi yang disampaikan oleh fasilitator pelatihan. Aplikasi e-learning dapat diakses oleh peserta melalui alamat https://pkbmdaring.moodlecloud.com dan peserta dapat masuk menggunakan surel yang digunakan peserta ketika melakukan registrasi kegiatan pelatihan. Halaman beranda aplikasi Moodle dapat dilihat pada Gambar 6. Selain itu, untuk menunjang kegiatan pelatihan, seluruh materi pelatihan dapat diunduh melalui tautan http://bit.ly/Materi_PKBMDaring1 dan rekaman video pelatihan dapat diputar ulang melalui Youtube melalui tautan https://www.youtube.com/watch?v=d8gJKa4QMrg. 


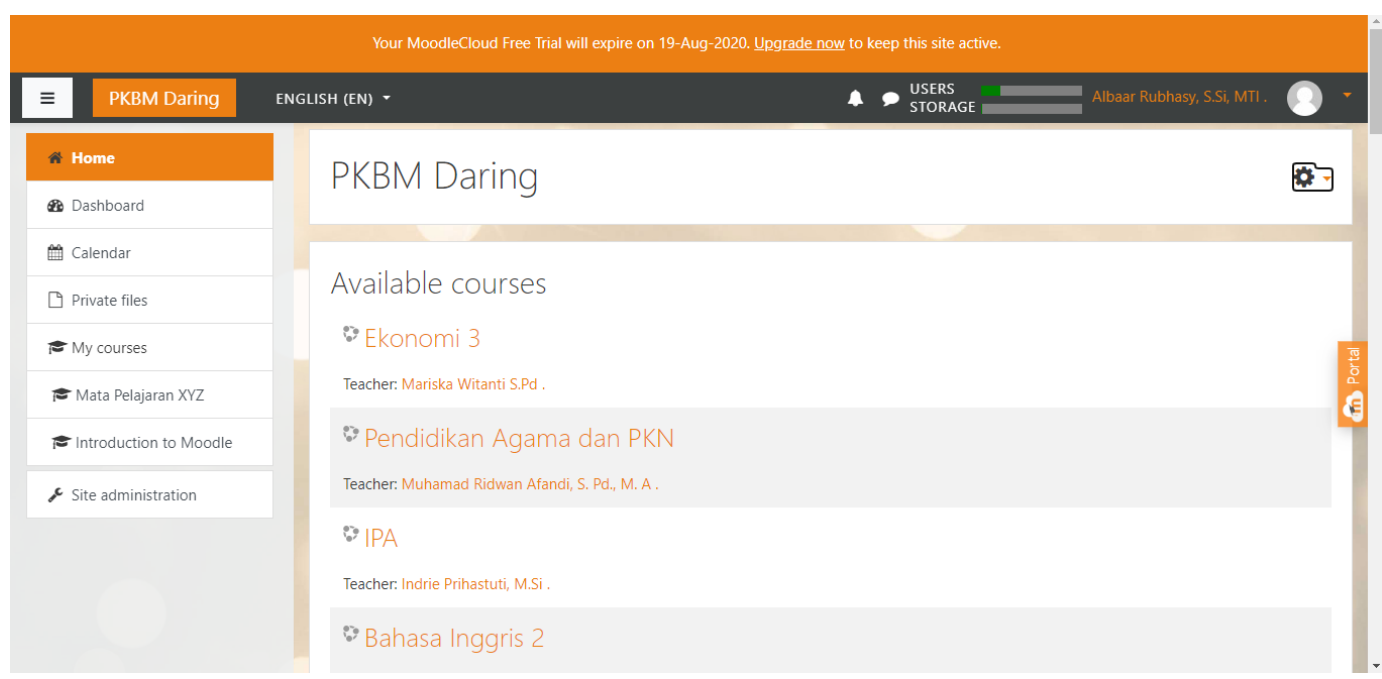

Gambar 6. Halaman Beranda CloudMoodle PKBM Daring

Materi pelatihan yang disampaikan kepada peserta mencakup tiga topik berikut:

1) Penjelasan umum mengenai aplikasi Moodle yang meliputi (lihat Gambar 7):
a) Konsep e-learning
b) Pengenalan Moodle
c) Fitur-fitur Moodle

2) Pelatihan pengelolaan materi pembelajaran yang meliputi (lihat Gambar 8):
a) Mengunggah materi ajar
b) Membuat kuis
c) Membuat tugas
d) Membuat forum diskusi

3) Pelatihan pengelolaan nilai yang meliputi (lihat Gambar 9):
a) Memasukkan nilai kuis
b) Memasukkan nilai tugas
c) Melihat nilai siswa
d) Mengunduh nilai siswa

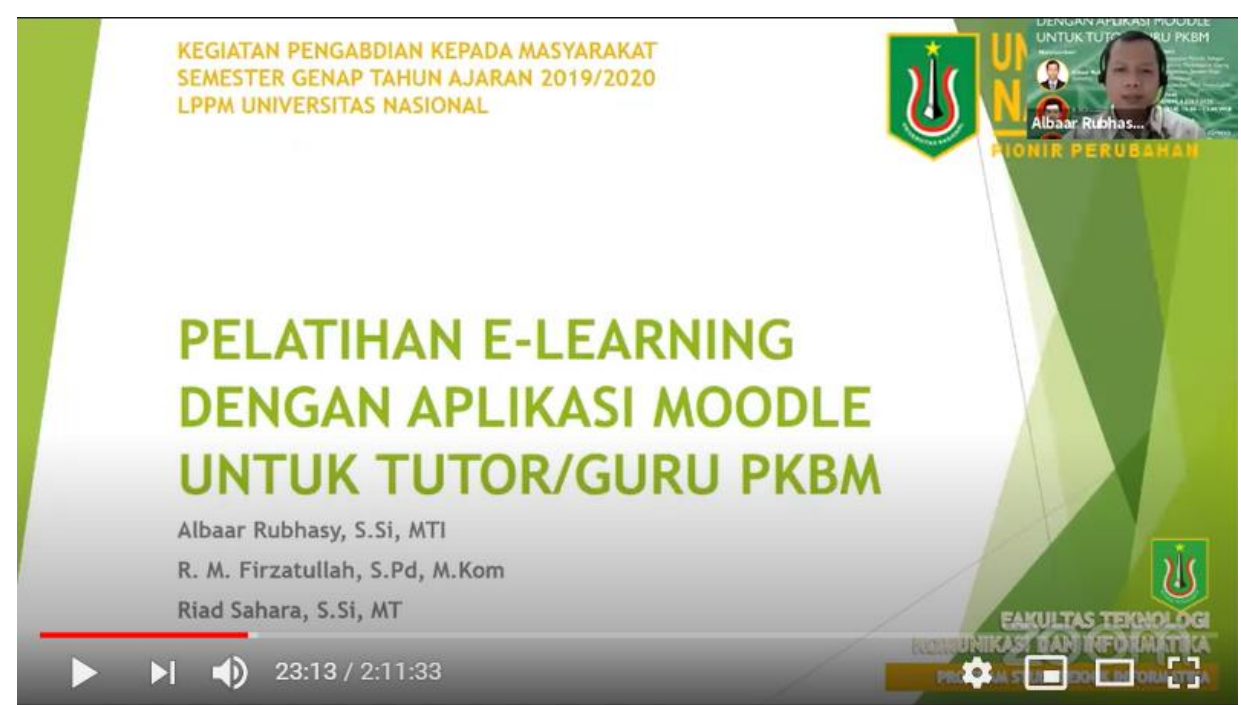

Gambar 7. Penjelasan Umum Mengenai E-Learning Moodle 
Terang: Jurnal Pengabdian Pada Masyarakat Menerangi Negeri

e-ISSN: $2655-5948$

Vol. 4, No. 1, Desember 2021

P-ISSN: 2655-5956

DOI: https://doi.org/10.33322/terang.v4i1.1249

Hal. $51-62$

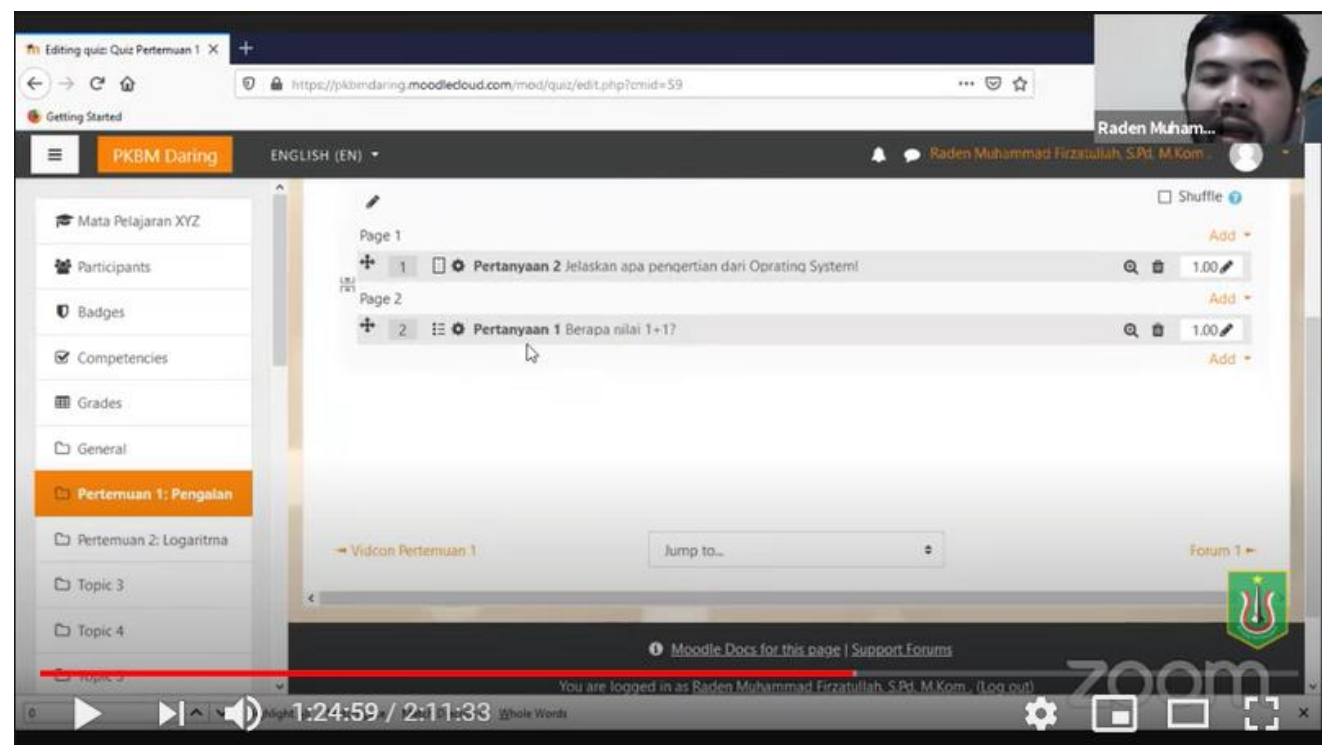

Gambar 8. Pelatihan Mengunggah Materi Ajar, Membuat Kuis, Tugas, dan Forum Diskusi

Setelah selesai penyampaian materi pelatihan, dilakukan evaluasi sebagai umpan balik terhadap pelaksanaan PKM. Adapun evaluasi dilakukan berdasarkan tiga aspek:

1) Pemahaman peserta terhadap materi pelatihan

2) Penyelenggaraan pelatihan

3) Narasumber pelatihan

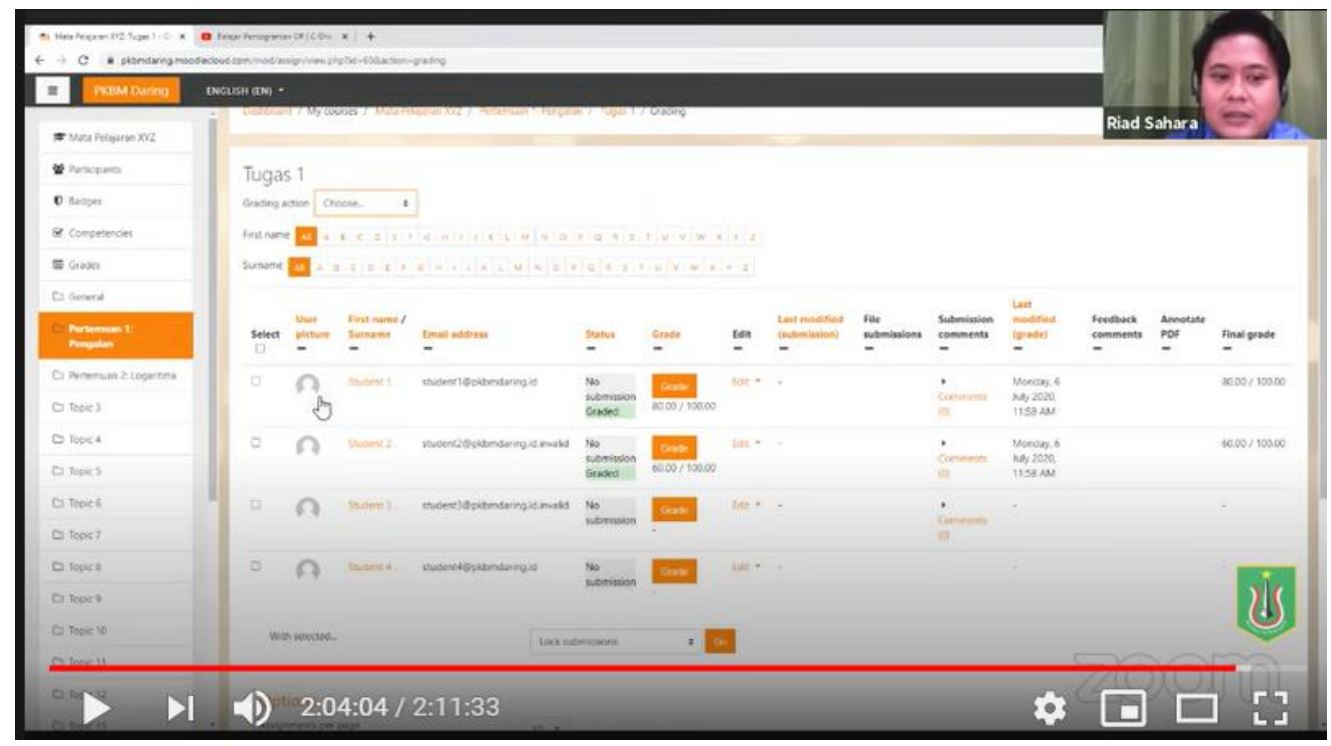

Gambar 9. Pelatihan Input dan Unduh Nilai Siswa

Hasil evaluasi kegiatan PKM dapat dilihat pada Tabel 4-6. 
Terang: Jurnal Pengabdian Pada Masyarakat Menerangi Negeri

e-ISSN: 2655-5948

Vol. 4, No. 1, Desember 2021

P-ISSN: 2655-5956

DOI: https://doi.org/10.33322/terang.v4i1.1249

Hal. $51-62$

Tabel 4. Evaluasi Kegiatan Pelatihan Berdasarkan Pemahaman Peserta Terhadap Materi Pelatihan

\begin{tabular}{|c|c|c|c|c|c|c|c|}
\hline No & Pernyataan & $\begin{array}{c}\text { Sangat } \\
\text { Tidak } \\
\text { Menguasai }\end{array}$ & $\begin{array}{c}\text { Tidak } \\
\text { Menguasai }\end{array}$ & $\begin{array}{c}\text { Cukup } \\
\text { Menguasai }\end{array}$ & Menguasai & $\begin{array}{c}\text { Sangat } \\
\text { Menguasai }\end{array}$ & Total \\
\hline & & 1 & 2 & 3 & 4 & 5 & \\
\hline 1 & $\begin{array}{l}\text { Saya dapat } \\
\text { mengunggah } \\
\text { materi } \\
\text { pembelajaran } \\
\text { menggunakan } \\
\text { Moodle }\end{array}$ & 0 & 1 & 9 & 17 & 1 & 28 \\
\hline 2 & $\begin{array}{l}\text { Saya dapat } \\
\text { membuat Quiz } \\
\text { menggunakan } \\
\text { Moodle }\end{array}$ & 1 & 1 & 8 & 16 & 2 & 28 \\
\hline 3 & $\begin{array}{l}\text { Saya dapat } \\
\text { berinteraksi } \\
\text { melalui Forum } \\
\text { Diskusi } \\
\text { menggunakan } \\
\text { Moodle }\end{array}$ & 0 & 1 & 12 & 12 & 3 & 28 \\
\hline 4 & $\begin{array}{l}\text { Saya dapat } \\
\text { membuat } \\
\text { Assignment } \\
\text { menggunakan } \\
\text { Moodle }\end{array}$ & 1 & 1 & 8 & 18 & 0 & 28 \\
\hline 5 & $\begin{array}{l}\text { Saya dapat } \\
\text { mengunduh } \\
\text { log aktivitas } \\
\text { pembelajaran } \\
\text { menggunakan } \\
\text { Moodle }\end{array}$ & 1 & 1 & 8 & 17 & 1 & 28 \\
\hline 6 & $\begin{array}{l}\text { Saya dapat } \\
\text { mengunduh } \\
\text { nilai hasil } \\
\text { pembelajaran } \\
\text { menggunakan } \\
\text { Moodle }\end{array}$ & 1 & 1 & 10 & 16 & 0 & 28 \\
\hline
\end{tabular}


Terang: Jurnal Pengabdian Pada Masyarakat Menerangi Negeri

e-ISSN: 2655-5948

Vol. 4, No. 1, Desember 2021

P-ISSN: 2655-5956

DOI: https://doi.org/10.33322/terang.v4i1.1249

Hal. $51-62$

Tabel 5. Evaluasi Kegiatan Pelatihan Berdasarkan Penyelenggaraan Pelatihan

\begin{tabular}{|c|l|c|c|c|c|c|c|}
\hline No & Pernyataan & $\begin{array}{c}\text { Sangat } \\
\text { Tidak } \\
\text { Baik }\end{array}$ & $\begin{array}{c}\text { Tidak } \\
\text { Baik }\end{array}$ & $\begin{array}{c}\text { Cukup } \\
\text { Baik }\end{array}$ & Baik & $\begin{array}{c}\text { Sangat } \\
\text { Baik }\end{array}$ & Total \\
\cline { 2 - 7 } & $\mathbf{1}$ & $\mathbf{2}$ & $\mathbf{3}$ & $\mathbf{4}$ & $\mathbf{5}$ & \\
\hline 1 & 0 & 0 & 3 & 12 & 13 & 28 \\
\hline 2 & $\begin{array}{l}\text { Kema pelatihan } \\
\text { waktu/suasana }\end{array}$ & 0 & 1 & 8 & 11 & 8 & 28 \\
\hline 3 & Kelengkapan materi & 0 & 0 & 5 & 13 & 10 & 28 \\
\hline 4 & 0 & 0 & 2 & 15 & 11 & 28 \\
\hline
\end{tabular}

Tabel 6. Evaluasi Kegiatan Pelatihan Berdasarkan Narasumber Pelatihan

\begin{tabular}{|c|l|c|c|c|c|c|c|}
\hline No & Pernyataan & $\begin{array}{c}\text { Sangat } \\
\text { Tidak } \\
\text { Baik }\end{array}$ & $\begin{array}{c}\text { Tidak } \\
\text { Baik }\end{array}$ & $\begin{array}{c}\text { Cukup } \\
\text { Baik }\end{array}$ & Baik & $\begin{array}{c}\text { Sangat } \\
\text { Baik }\end{array}$ & Total \\
\cline { 2 - 7 } & $\mathbf{1}$ & $\mathbf{2}$ & $\mathbf{3}$ & $\mathbf{4}$ & $\mathbf{5}$ & \\
\hline 2 & $\begin{array}{l}\text { Penguasaan Konten/ } \\
\text { Substansi Pelatihan }\end{array}$ & 0 & 0 & 3 & 11 & 14 & 28 \\
\hline 3 & 0 & 0 & 8 & 13 & 7 & 28 \\
Metode yang & $\begin{array}{l}\text { Cara/teknik } \\
\text { penyajian }\end{array}$ & 0 & 0 & 5 & 16 & 7 & 28 \\
\hline 4 & $\begin{array}{l}\text { Interaksi dengan } \\
\text { peserta }\end{array}$ & 0 & 1 & 10 & 10 & 7 & 28 \\
\hline 5 & $\begin{array}{l}\text { Pengelolaan } \\
\text { pelatihan } \\
\text { penguasaan event } \\
\text { dan pengelolaan } \\
\text { waktu) }\end{array}$ & 0 & 1 & 7 & 10 & 10 & 28 \\
\hline
\end{tabular}




\section{KESIMPULAN}

Kegiatan PKM Semester Genap tahun Ajaran 2019/2020 berupa pelatihan E-learning Moodle Berbasis Cloud Untuk Tutor/Guru PKBM telah selesai diselenggarakan. Beberapa kesimpulan yang diperoleh dari kegiatan PKM ini antara lain:

1) E-learning Moodle berbasis Cloud dalam memudahkan tutor/guru PKBM dalam penyelenggaraan pembelajaran karena pembelajaran dapat dilakukan kapan pun dan dimana pun sesuai dengan kemampuan peserta ajar.

2) Peserta pelatihan yang mengikuti kegiatan adalah sebanyak 31 peserta yang berasal dari lebih dari 10 institusi PKBM dan sebagian besar peserta memiliki pengalaman dalam menggunakan e-learning.

4) Materi pelatihan disampaikan secara interaktif dengan materi antara lain: (i) penjelasan umum mengenai aplikasi Moodle; (ii) pelatihan pengelolaan materi pembelajaran; dan (iii) Pelatihan pengelolaan nilai.

5) Pelatihan telah diselenggarakan dengan baik berdasarkan umpan balik yang disampaikan oleh peserta dipandang dari tiga aspek: (i) pemahaman peserta terhadap materi pelatihan; (ii) penyelenggaraan pelatihan; dan (iii) narasumber pelatihan.

\section{SARAN}

Kegiatan PKM yang telah dilaksanakan ini merupakan tahap awal dari rangkaian kegiatan lainnya yang dapat dikembangkan. Berdasarkan pengamatan dan masukan dari peserta pelatihan, beberapa kegiatan yang dapat dilaksanaan di masa mendatang meliputi:

1) Pelatihan penggunaan e-learning Moodle untuk peserta ajar

2) Pelatihan pengajaran daring secara efektif

3) Pelatihan pembuatan materi ajar berbasis multimedia

\section{UCAPAN TERIMA KASIH}

Kegiatan Pengabdian Kepada Masyarakat ini didanai oleh Lembaga Penelitian dan Pengabdian Kepada Masyarakat Universitas Nasional.

\section{DAFTAR PUSTAKA}

[1] Undang-Undang Dasar Negara Republik Indonesia Tahun 1945, 10 Agustus 2002. UndangUndang Dasar, Jakarta.

[2] Undang-Undang Republik Indonesia Nomor 20 Tahun 2003, 8 Juli 2003, Sistem Pendidikan Nasional. Lembaran Negara Republik Indonesia Tahun 2003 Nomor 78, Tambahan Lembaran Negara Republik Indonesia Nomor 4301, Jakarta.

[3] Peraturan Pemerintah Republik Indonesia Nomor 17 Tahun 2010, 23 Januari 2020, Pengelolaan dan Penyelenggaraan Pendidikan, Lembaran Negara Republik Indonesia Tahun 2010 Nomor 23, Tambahan Lembaran Negara Republik Indonesia Nomor 5105, Jakarta.

[4] Kementerian Perencanaan Pembangunan Nasional/Bappenas, 2017, Terjemahan Tujuan dan Target Global Tujuan Pembangunan Berkelanjutan (TPB), http://sdgs.bappenas.go.id/ dokumen/, diakses tanggal 22 Agustus 2020.

[5] Kementerian Perencanaan Pembangunan Nasional/Bappenas, 2020, Rencana Pembangunan Jangka Menengah Nasional 2020-2024, https://drive.bappenas.go.id/owncloud/index.php/s/ 4q7Cb7FBxavq31K, diakses tanggal 22 Agustus 2020. 
[6] Fatma, A.M., 2018, Peran Tutor Dalam Mengembangkan Motivasi Berprestasi Warga Belajar Paket C di PKBM Dharma Bekti Kecamatan Cibinong Bogor, Jurnal Eksistensi Pendidikan Luar Sekolah (E-PLUS), No. 2, Vol. 3, Hlm. 193-204.

[7] Peraturan Pemerintah Republik Indonesia Nomor 47 Tahun 2008, 4 Juli 2008, Wajib Belajar, Lembaran Negara Republik Indonesia Tahun 2008 Nomor 90, Jakarta.

[8] Rogers, A., 2019, Second-generation non-formal education and the sustainable development goals: operationalising the SDGs through community learning centres, International Journal of Lifelong Education, 38(5), pp.515-526.

[9] Lousada, L., 2013, E-learning Tools in Non-formal Education Environments, ICT Conference proceedings for language learning, pp. 184-188. 